\title{
MANAJEMEN PELATIHAN GURU PAI DALAM MENINGKATKAN KOMPETENSI IT UNTUK MEWUJUDKAN MUTU PEMBELAJARAN SISWA \\ Yani Sumarni
}

Universitas Islam Nusantara Bandung, Indonesia E-mail: sumarniyani1972@gmail.com

Diterima:

10 September 2021

Direvisi:

28 September

2021

Disetujui:

28 September

2021

\section{Abstrak}

Penelitian ini dilatar belakangi oleh kesiapan guru Pendidikan Agama Islam menjadikan Teknologi Informasi (TI) misalnya komputer, internet dan sejenisnya sebagai sarana dan media pembelajaran Pendidikan Agama Islam agar lebih optimal. Berdasarkan realitas, aplikasi (TI) pada waktu pembelajaran Pendidikan Agama Islam di sekolah. Pembelajaran Pendidikan Agama Islam masih banyak menggunakan cara-cara konvensional seperti ceramah, tanya jawab dan metode lain yang berpusat pada guru (teacher-centered).Tujuan penelitian ini adalah untuk mengetahui bagaimana perencanaan, pelaksanaan, evaluasi, faktor pendukung dan penghambat manajemen pelatihan guru PAI dalam meningkatkan kompetensi IT untuk mewujudkan mutu pembelajaran siswa di KKG PAI Kecamatan Ciranjang dan Kecamatan Takokak Kabupaten Cianjur. Penelitian ini menggunakan pendekatan kualitatif yang tidak mencari sebab akibat, namun lebih berupaya memahami situasi tertentu dengan bentuk penelitian studi kasus (case study) yaitu suatu penelitian yang dilakukan secara intensif, terinci dan mendalam terhadap suatu organisasi, lembaga atau gejala tertentu. Menurut penelitian kualitatif data yang dapat diperoleh berasal dari naskah wawancara, observasi, catatan lapangan, dokumen pribadi, cacatan memo dan dokumen resmi lainnya dengan tujuan mendeskripsikan realitas empiris di balik fenomena yang ada secara mendalam, rinci dan tuntas. Hasil penelitian ini menunjukkan bahwa manajemen pelatihan guru PAI dalam meningkatkan kompetensi IT untuk mewujudkan mutu pembelajaran siswa di KKG PAI Kecamatan Ciranjang dan Kecamatan Takokak Kabupaten Cianjur cukup efektif. Efektivitas tersebut terlihat dari pola manajemen organisasi yang dilakukan oleh pengurus KKG tersebut. Organisasi berjalan dengan baik, pola manajemen yang dilakukan dengan bertumpu pada empat fungsi manajemen juga berlangsung baik. Peningkatan kompetensi IT guru PAI di lingkup KKG PAI Kecamatan Ciranjang dan Kecamatan Takokak Kabupaten Cianjur cukup efektif berdasarkan observasi, wawancara dan dokumentasi yang peneliti lakukan.

Kata kunci: Manajemen, Pelatihan, Guru PAI

\section{Abstract}

This research is motivated by the readiness of Islamic Religious Education Teachers to make information technology (IT) such as computers, the internet and the like as a means and media for 


\section{Pendahuluan}

Kehadiran Teknologi Informasi dalam pembelajaran pendidikan agama Islam di sekolah sebagai media pembelajaran menjadi sangat penting, terutama dalam meningkatkan efektivitas proses belajar mengajar. Teknologi Informasi juga dapat membantu siswa cepat memahami materi yang dipelajari secara bulat dan utuh. Oleh karena itu, para cendekiawan sepakat pada suatu argumen bahwa Teknologi Informasi memudahkan kehidupan manusia tanpa harus kehilangan rasa sosial humanisme yang dimiliki. Persoalannya ialah adakah kesiapan Guru Pendidikan Agama Islam menjadikan Teknologi Informasi (TI) semisal komputer, internet dan sejenisnya sebagai sarana dan media pembelajaran Pendidikan Agama Islam agar lebih optimal. Menurut realitas, aplikasi Teknologi Informasi (TI) pada waktu pembelajaran Pendidikan Agama Islam di sekolah masih jauh panggang dari api. Pembelajaran Pendidikan Agama Islam masih 
banyak menggunakan cara-cara konvensional seperti ceramah, tanya jawab dan metode lain yang berpusat pada guru (teacher- centered). Pembelajaran daring pada masa Covid19 saat ini memang menjadi dilema bagi guru dan siswa. Proses pembelajaran harus berjalan, disisi lain, berbagai problematika mengiringi proses pelaksanaannya. Kesulitankesulitan (problems) yang muncul dalam pembelajaran daring adalah suatu tantangan. Oleh karena itu, seluruh stakeholders seperti pemangku kebijakan (Kemendikbud), kepala sekolah, guru, orangtua dan siswa harus saling bekerja sama untuk mensuksekan pelaksanaan pembelajaran daring.

Ketidaksiapan ini dikarenakan pola kebiasaan pembelajaran yang masih belum menganggap penting peranan TIK dalam meningkatkan mutu pembelajaran. Mereka cenderung sudah merasa puas akan materi yang telah diberikan oleh pengajar secara langsung, sehingga mereka tidak mau dan malas untuk mencari informasi tambahan yang ada di internet walaupun sarana dan infrastruktur sudah mendukung dalam penerapan TIK. Kenyataan lain bahwa gairah para guru untuk memainkan peran sebagai objek pendidikan yang juga belajar untuk meningkatkan kompetensinya, masih rendah. Hal ini dapat dilihat dari bagaimana sikap para guru dalam menghadapi pergantian kurikulum. Kegagapan para guru dalam beradaptasi dengan kurikulum baru menunjukkan bahwa jiwa pembelajar pada mayoritas guru kita masih minim. Semestinya para guru menjadikan momentum pergantian kurikulum ataupun berbagai tantangan dunia pendidikan sebagai peluang untuk belajar bukan sebagai ancaman.

Setidaknya ada 2 (dua) faktor yang menyebabkan mengapa para guru ini kurang berminat menjadikan Teknologi Informasi sebagai media pembelajaran, yaitu pertama, faktor internal, yaitu lemahnya kapasitas dan skill mereka terhadap piranti seperti komputer, laptop, notebook, internet dan sejenisnya. Kedua, faktor eksternal yaitu kondisi lingkungan kerja yang kurang kondusif, misalnya keterbatasan dana yang dimiliki sekolah atau guru, listrik yang kurang memadai dan persepsi para pelaku pendidikan yang menganggap belum mendesaknya kehadiran Teknologi Informasi dalam pembelajaran Pendidikan Agama Islam (Rohmad, 2014).

Padahal keberadaan ICT dalam dunia pendidikan sudah dianggap merupakan kebutuhan mutlak. Bahkan Badan pendidikan dunia, UNESCO, dalam beberapa publikasinya menyatakan pentingnya pemanfaatan ICT dalam bidang pendidikan. Tim gabungan Kementerian Komunikasi dan Informasi, departemen Pendidikan Nasional (Kementerian Pendidikan dan Kebudayaan) serta Departemen Agama (Kementerian Agama) mengidentifikasi beberapa peranan strategis Teknologi Informasi dan Komunikasi dalam Sistem Pendidikan Dasar dan Menengah. Peranan itu ialah :

1) sebagai gudang ilmu pengetahuan

2) sebagai alat bantu pembelajaran

3) sebagai fasilitas pendidikan

4) sebagai standar kompetensi

5) sebagai penunjang administrasi pendidikan

6) sebagai alat bantu manajemen sekolah/madrasah

7) sebagai infrastruktur pendidikan.

Sejak tahun 2004 Indonesia telah menandatangani komitmen dalam World Summit onInformation Society (WSIS) yang salah satu butirnya menyatakan bahwa pada tahun 2015 paling tidak 50\% dari populasi penduduk harus dapat memanfaatkan Teknologi Informasi untuk meningkatkan kualitas hidup (Afifuddin, 2017).

Berdasarkan Peraturan Pemerintah RI Nomor 19 tahun 2005 tentang Standar Nasional Pendidikan, Pasal 28 dinyatakan bahwa kualitas guru dibuktikan dengan kompetensi-kompetensi. Kompetensi merupakan gambaran hakikat kualitatif dari 
perilaku seseorang. Kompetensi merupakan kapasitas untuk melakukan sesuatu, yang dihasilkan dari proses belajar. Selama proses belajar stimulus akan bergabung dengan isi memori dan menyebabkan terjadinya perubahan kapasitas untuk melakukan sesuatu yang berlangsung lama yang menyebabkan individu mampu melakukan kinerja tertentu. Oleh karena itu merupakan suatu keharusan bagi guru untuk meningkatkan kompetensinya sesuai standar-standar yang telah ditetapkan oleh pemerintah (UU RI No 19, 2006:92-93).

Menurut Brand dalam Educational Leadership yang dikutip oleh E.Mulyasa menyatakan bahwa "hampir semua usaha reformasi pendidikan seperti pembaharuan kurikulum dan penerapan metode pembelajaran, semuanya tergantung kepada guru. Tanpa penguasaan materi dan strategi pembelajaran, serta tanpa dapat mendorong siswanya untuk belajar sungguh-sungguh, segala upaya peningkatan mutu pendidikan tidak akan mencapai hasil yang maksimal (Mulyasa, 2013).

Berdasarkan uraian tersebut, nampak bahwa salah satu upaya yang perlu mendapat perhatian yang utama dalam meningkatkan kualitas pendidikan adalah peningkatan kualitas guru atau dengan kata lain bahwa sejalan dengan usaha yang telah dilakukan pemerintah sebagai penyedia pendidikan dalam usaha peningkatan mutu pendidikan, peningkatan kompetensi guru merupakan hal mutlak yang mesti diperhatikan. Tanpa peningkatan kompetensi guru, maka usaha yang dilakukan pemerintah dalam meningkatkan mutu pendidikan tidak akan berdampak nyata, khususnya dalam kegiatan belajar mengajar dikelas.

Secara khusus, belajar mengajar bukanlah sesuatu yang bersifat pasti, sebab penentuan langkah-langkah pembelajaran dipengaruhi oleh faktor-faktor sekelilingnya yang ikut menentukan keberhasilan suatu proses belajar mengajar. Beberapa aspek strategi belajar mengajar yang memeberikan pengaruh kepada efektivitas suatu proses belajar mengajar adalah tahapan langkah-langkah, prinsip-prinsip reaksi guru dan siswa, sistem sosial dan sistem penunjang lainnya (Sofyan Sauri, 2017).

Pemerintah semestinya selalu berusaha meningkatkan kompetensi guru secara bertahap, baik melalui penataran-penataran, melanjutkan pendidikan ke jenjang yang lebih tinggi, maupun dengan menggalakkan berbagai workshop dan seminar yang diadakan baik ditingkat pusat, maupun daerah masing-masing. kegiatan pembinaan guru merupakan bagian yang tak terpisahkan dalam setiap usaha peningkatan mutu pembelajaran.

Tantangan yang dihadapi dalam dunia pendidikan semakin kompleks, maka konsekuensinya guru sebagai pelaku utama dituntut untuk meningkatkan peranan dan kemampuannya untuk mengahadapi tantangan tersebut. berkaitan dengan jabatan dan profesi sebagai seorang guru, fenomena sekarang terlihat di beberapa tempat bahwa masih terdapat guru yang belum memiliki keahlian yang diperolehnya melalui pendidikan dan ditunjukkan dengan sertifikasi atau ijazah dan kata yang sesuai dengan mata pelajaran yang diajarkannya.

Perubahan dan pembaharuan sistem pendidikan sangat bergantung pada "what teachers do and think" atau dengan kata lain bergantung pada penguasaan kompetensi guru. Sudarwan Danim mengungkapkan bahwa salah satu ciri krisis pendidikan di Indonesia adalah guru belum mampu menunjukkan kinerja (work performance) yang memadai (Anggreni, 2016). Hal ini menunjukkan bahwa kinerja guru belum sepenuhnya ditopang oleh derajat penguasaan kompetensi yang memadai.

Kualifikasi guru berkaitan erat dengan kompetensi yang dimiliki guru, baik kompetensi tingkat pendidikan, keilmuan dan profesional. Kompetensi tingkat pendidikan merupakan tingkat pendidikan yang dipersyaratkan bagi seorang guru, untuk mengajar di tingkat sekolah tertentu. Sedangkan kompetensi keilmuan adalah kesesuaian antara basis 
keilmuan yang diperoleh selama di perguruan tinggi dengan mata pelajaran yang diajar. Kompetensi profesi adalah pelatihan-pelatihan yang diikuti yang berguna untuk memperkuat kemampuan profesinya dan lazimnya dibuktikan dengan uji kompetensi, lisensi dan sertifikasi, sehingga dapat menggambarkan "track record" guru yang bersangkutan dalam perjalanan aspek profesionalnya (Mulyawan, 2013). "Manajemen Pendidikan Berbasis Nilai" menyatakan bahwa tugas guru tidak bisa dilakukan oleh sembarang orang, melainkan hanya oleh orang yang memiliki kapasitas keilmuan memadai dalam bidang pendidikan. ia harus paham mengenai dasar- dasar ilmu mendidik, mengajar dan melatih, dimana kualifikasi akademik yang dimiliki haruslah sarjana pendidikan dan bukan orang lain (H. Sofyan Sauri, 2019).

Kompetensi adalah tindakan atau kinerja yang menggambarkan potensi, pengetahuan, keterampilan dan sikap, yang terkait dengan profesi tertentu (Rivalina, 2015). Definisi tersebut menunjukkan bahwa kompetensi merupakan suatu kesatuan utuh yang menggambarkan penampilan, kemampuan dan perilaku seseorang. Menurut teori konvergensi, kompetensi terbentuk dari perpaduan potensi- potensi dalam diri manusia dengan lingkungannya (Uno \& Lamatenggo, 2016). Artinya manusia lahir membawa sejumlah potensi atau kemampuan lahiriyah yang kemudian berinteraksi dengan lingkungan sekitarnya (termasuk pendidikan) sehingga membangun sebuah kompetensi baru yang lebih matang.

Peraturan Menteri Pendidikan Nasional No. 16 Tahun 2007 menjelaskan bahwa kompetensi pedagogik adalah pemahaman terhadap peserta didik, perancangan dan pelaksanaan pembelajaran, evaluasi hasil belajar dan pengembangan peserta didik untuk mengaktualisasikan berbagai potensi yang dimilikinya; Kompetensi profesional adalah penguasaan materi pembelajaran secara luas dan mendalam, yang mencakup penguasaan materi kurikulum mata pelajaran di sekolah dan substansi keilmuan yang menaungi materinya, serta penguasaan terhadap struktur dan metodologi keilmuannya; Kompetensi kepribadian adalah kemampuan personal yang mencerminkan kepribadian yang mantap, stabil, dewasa, arif, berwibawa, menjadi teladan bagi peserta didik dan berakhlak mulia; dan Kompetensi sosial adalah kemampuan guru dalam berkomunikasi dan bergaul secara efektif dengan peserta didik, tenaga kependidikan, orang tua/wali peserta didik dan masyarakat sekitar (Sulfemi, 2019).

Salah satu indikator kompetensi guru yang menjadi perhatian penulis adalah kompetensi Teknologi Informasi dan Komunikasi (TIK). Kompetensi TIK guru adalah kemampuan guru dalam mengembangkan inovasi pembelajaran dengan memanfaatkan TIK baik dalam merencanakan, melaksanakan, maupun mengevaluasi pembelajaran, baik pada aspek kompetensi pedagogi, personal, profesional, maupun sosial. Menurut Peraturan Menteri Pendidikan Nasional Nomor 16 Tahun 2007, kompetensi TIK bagi guru sekurang-kurangnya mempunyai dua fungsi, yaitu TIK sebagai pengembangan diri dan TIK sebagai penunjang proses pembelajaran (Niarsa, 2013).

Penetapan kompetensi TIK sebagai salah satu kompetensi guru adalah merupakan konsekuensi logis terhadap besarnya pengaruh positif TIK bagi aktivitas pendidikan, seperti: mempercepat akses guru ke berbagai sumber belajar, mempercepat pekerjaan administrasi guru, membantu guru dalam menjelaskan materi yang bersifat abstrak dan rumit dan mempermudah guru dalam mengirimkan laporan kinerjanya ke portal pemerintah (Batubara, 2015). Oleh karena itu, guru di samping memiliki kemampuan mengajar di kelas juga harus mampu mengintegrasikan pemanfaatan TIK dalam pembelajaran.

Teknologi Informasi merupakan teknologi yang menggabungkan komputerisasi (komputer) dengan jalur komunikasi berkecepatan tinggi yang membawa data, suara dan video. Mereka merupakan kombinasi dari komputer yang berhubungan dengan saluran 
komunikasi dengan transmisi data kecepatan tinggi dalam bentuk teks, audio dan video (Nugroho, Pramukanto, Negara, Purnomowati, \& Wulandari, 2016). Sebagai tenaga pendidik sudah seharusnya mengikuti arus zaman yang sedang mengalir seperti air yang tidak bisa dihindari dan pungkiri. Di zaman teknologi yang serba instan diharapkan untuk tidak gaptek mulai dari kalangan anak- anak, dewasa sampai yang tua. Begitu juga dengan tenaga pendidik, diharapkan untuk melek dalam penggunaan IT sebagai penunjang pembelajaran yang menarik (Asilestari, 2016). Maka dari itu guru sebagai tenaga pendidik dituntut untuk selalu melakukan perubahan-perubahan terutama dalam penggunaan IT untuk menuju guru yang profesional.

Kemampuan profesional seorang guru tidak lahir secara alamiah, melainkan membutuhkan pendidikan dan pelatihan khusus dalam waktu yang relatif Panjang sehingga terbentuk tenaga pendidik yang profesional. Agar tujuan pendidikan dalam meningkatkan mutu pembelajaran anak didik bisa tercapai maka upaya untuk meningkatkan kemampuan profesional guru dipandang penting. Usaha meningkatkan professional guru salah satunya melalui pengembangan program pelatihan kelompok kerja guru (KKG). Ini adalah sebagai upaya dalam meningkatkan kompetensi profesional guru agar dapat mensukseskan tujuan pembelajaran yang sudah dicanangkan sebelumnya.

Salah satu upaya dalam meningkatkan kompetensi guru PAI adalah melalui pelatihan. Pelatihan merupakan salah satu usaha dalam meningkatkan mutu guru. Guru sangat membutuhkan bantuan khusus dalam mengasah atau mengembangkan keterampilan-keterampilan profesional peserta didik. Salah satu program yang dapat mengasah dan mengembangkan keterampilan adalah melalui pelatihan yang sistematik, artinya kegiatan pelatihan harus dilaksanakan secara kontinyu dan berulang dengan pentahapan yang terencana dan teratur (Utomo, 2016).

Upaya lain yang mesti dilaksanakan dalam meningkatkan kompetensi IT guru PAI adalah melalui, workshop, seminar dan lain sebagainya. Hal ini penting dan bermanfaat bagi seorang guru, khususnya guru PAI yang berkaitan dengan moral dan akhlak siswa. Proses belajar dan mutu pembelajaran siswa bukan saja ditentukan oleh sekolah, pola, struktur dan isi kurikulumnya, akan tetapi sebagian besar ditentukan oleh kompetensi guru yang mengajar dan membimbing mereka. Salah satu faktor yang paling menentukan berhasilnya mutu pembelajaran adalah guru. Guru yang kompeten akan lebih mampu menciptakan lingkungan belajar yang efektif, menyenangkan dan akan lebih mampu mengelola kelasnya, sehingga proses pembelajaran berada pada tingkat optimal.

Pelatihan merupakan tahapan penting pengembangan SDM guru secara keseluruhan. Hal itu tidak hanya terkait dengan pengembangan karir profesional tetapi juga untuk pengembangan sekolah. Ferreira (2013), mengemukakan bahwa pelatihan guru memberi bekal pengetahuan dan keterampilan yang dapat digunakan dalam mengajar, membuka inspirasi, mampu mengelola kelas dengan baik dan mengembangkan kompetensi dan profesional.

Pelatihan untuk guru sangat diperlukan, karena program pembelajaran merupakan kerangka konseptual yang menggambarkan prosedur yang teratur dan sistematis yang berfungsi sebagai pedoman perencanaan, pelaksanaan, evaluasi, dan tindak lanjut dalam kegiatan belajar mengajar. Guru sebagai pendidik berkewajiban untuk menciptakan suasana Pendidikan yang bermakna, menyenangkan, kreatif dan dinamis, serta dialogis. Guru merupakan faktor penentu bagi keberhasilan pendidikan di sekolah, karena guru merupakan sentral serta sumber kegiatan belajar mengajar yang berpengaruh dalam peningkatan mutu pendidikan di sekolah. 
Pengembangan program pelatihan Kelompok Kerja Guru (KKG) PAI sangat strategis untuk meningkatkan kompetensi profesional guru, antara lain melalui berbagai program pelatihan seperti pelatihan dalam pembuatan modul belajar, pelatihan tentang pengembangan desain pembelajaran, pelatihan dalam mengembanan alat evaluasi, pelatihan tentang penggunaan media pembelajaran, pelatihan dalam penyusunan rencana pembelajaran, kemudian bisa juga melalui peningkatan sarana dan prasarana (fasilitas), serta peningkatan kualitas KKG PAI itu sendiri. Di samping itu belum adanya ramburambu yang dapat dijadikan acuan bagi guru dan pengurus KKG PAI dalam melakukan aktivitas kelompok kerja guru serta belum intensifnya program pendampingan yang dilaksanakan instruktur terhadap guru sebagai tindak lanjut pelaksanaan kegiatan.

Berdasarkan pemikiran di atas, manajemen pelatihan guru PAI dalam meningkatkan kompetensi IT untuk mewujudkan mutu pembelajaran siswa sangatlah penting dalam upaya mewujudkan mutu pembelajaran siswa pada umumnya dan mutu guru pada khususnya. Oleh karena itu, penelitian ini bermaksud untuk memahami manajamen pelatihan guru PAI yang mencakup perencanaan, pelaksanaan dan sistem evaluasinya, dalam rangka peningkatan kompetensi guru sebagaimana yang diterapkan pada KKG PAI yang akan diteliti.

Hal inilah yang dilakukan oleh kegiatan Kelompok Kerja Guru (KKG) PAI di Kecamatan Ciranjang dan Kecamatan Takokak sebagai upaya dalam meningkatkan kompetensi IT guru PAI. Agar mereka menjadi guru yang profesional yang mampu membawa perubahan bagi pendidikan dalam proses pembelajaran sehingga mampu meningkatkan mutu pembelajaran peserta didik dan mampu mensukseskan tujuan pembelajaran dengan baik. Sehingga visi misi sekolah atau madrasah yang telah dicanangkan dan tujuan pembelajaran yang telah dirumuskan dapat diraih dengan baik dan sempurna.

Tujuan Penelitian ini adalah untuk mengetahui perencanaan pelatihan guru PAI dalam meningkatkan kompetensi IT untuk mewujudkan mutu pembelajaran siswa di KKG Kecamatan Ciranjang dan Kecamatan Takokak. Hasil penelitian ini diharapkan dapat mengembangkan hasanah keilmuan berkaitan dengan pelatihan guru PAI dalam meningkatkan kompetensi guru PAI untuk mewujudkan mutu pembelajaran siswa di KKG Kecamatan Ciranjang dan Kecamatan Takokak.

\section{Metode Penelitian}

Penelitian ini menggunakan pendekatan kualitatif yang tidak mencari sebab akibat, namun lebih berupaya memahami situasi tertentu dengan bentuk penelitian studi kasus (case study) yaitu suatu penelitian yang dilakukan secara intensif, terinci, dan mendalam terhadap suatu organisasi, lembaga atau gejala tertentu.

Penelitian ini merupakan upaya untuk memahami dan mendeskripsikan peningkatan kompetensi guru PAI termasuk upaya mengungkap faktor-faktor yang menjadi hambatan dalam peningkatan kompetensi IT guru PAI melalui pelatihan. Desain penelitian yang tepat yaitu naturalistik atau alamiah. Berbagai jenis penelitian inkuiri naturalistik menurut Bogdan dan Biklen yaitu etnografi, interaksionis simbolik, perspektif ke dalam, etnometodologi, studi kasus, interpretatif ekologis dan deskriptif, termasuk fenomenologis. Penelitian dengan paradigma naturalistik menuntut dilaksanakannya penelitian dalam konteks naturalistik, dengan harapan makna yang diangkat dari penelitian tersebut memang dari konteksnya, bukan dari prakonsep penelitiannya. Pemaknaan hasil wawancara atau observasi menjadi hal yang penting dalam kontek penelitian ini. 


\section{Hasil dan Pembahasan}

\section{Manajemen Pelatihan Guru PAI dalam Meningkatkan Kompetensi IT Untuk Mewujudkan Mutu Pembelajaran Siswa di KKG PAI Kecamatan Ciranjang}

\section{a. Perencanaan}

Program atau aktivitas selalu diawali dengan adanya perencanaan. Perencanaan atau planning merupakan salah satu dari fungsi manajemen yang sangat penting. Sebuah rencana sangat mempengaruhi sukses dan tidaknya suatu pekerjaan. Oleh karena itu, pekerjaan yang baik adalah yang direncanakan. Dengan demikian dapat diketahui bahwa dalam suatu perencanaan, memuat unsur: (1) sesuatu yang berhubungan dengan masa depan, (2) seperangkat kegiatan, (3) proses yang sistematis dan (4) hasil serta tujuan tertentu yang hendak dicapai.

Upaya mewujudkan tujuan yang hendak dicapai tersebut yakni untuk meningkatkan mutu pendidikan dan kompetensi guru, KKG PAI SD di Kecamatan Ciranjang telah membentuk serangkaian kegiatan yang diawali dengan pemilihan pengurus KKG PAI SD beserta seksi atau bidang yang dapat dijadikan sebagai tolok ukur tugas dan tanggung jawab dalam pengimplementasian program KKG PAI SD di Kecamatan Ciranjang kabupaten Cianjur, dalam rangka meningkatkan kegiatan KKG PAI Kecamatan Ciranjang Kabupaten Cianjur, perlu adanya rencana kegiatan yang tersusun dengan baik sehingga arah kegiatan akan berjalan sesuai dengan program yang telah ditentukan. Harapannya adalah dapat terlaksananya secara baik dan mencapai tujuan yang optimal dengan kinerja yang efesien.

Temuan penelitian menunjukkan bahwa keberadaan KKG PAI perlu dukungan semua guru PAI dan kerja sama dengan seluruh komponen kependidikan yang meliputi unsur manajemen personal maupun keuangan dimana hal ini sangat bergantung pada instansi tempat tugas guru tersebut. selain itu untuk meningkatkan peran KKG PAI agar mampu berkiprah secara mandiri perlu diupayakan agar KKG PAI dapat mencari terobosan untuk pembiayaan setiap kegiatannya dengan pihak lain dengan cara yang benar sehingga KKG PAI mampu berperan dalam meningkatkan kompetensi guru PAI melalui berbagai kegiatan yang direncanakan tanpa banyak membebani anggotanya.

Selama ini KKG PAI Ciranjang Kabupaten Cianjur telah berperan aktif memberikan sumbangsihnya kepada guru PAI melalui berbagai kegiatan yang diadakan. Namun kiranya perlu adanya peningkatan seiring dengan tuntutan peningkatan kualitas hasil pendidikan yang dibarengi pula dengan upaya peningkatan kualitas administrasi sebagai tenaga guru yang selalu dituntut pro-aktif dalam setiap kegiatan. Hal yang demikian menuntut setiap kegiatan perlu direncanakan sebaik-baiknya sehingga pada akhirnya mampu meraih hasil yang terbaik yang ditandai dengan peningkatan mutu dalam setiap kegiatan.

Kelompok kerja guru di Kecamatan Ciranjang merupakan wadah atau forum kegiatan profesional semua guru PAI tingkat SD untuk meningkatkan pengetahuan dan kemampuan serta membina hubungan kerjasama secara koordinatif dan fungsional antara sesama guru PAI di wilayah Kecamatan Ciranjang yang di dalamnya memiliki program sebagaimana organisasi yang lain. Adanya peran kelompok kerja guru di Kecamatan tersebut merupakan organisasi keprofesian guru pendidikan agama Islam di Sekolah Dasar tingkat kecamatan yang aktif dan dapat memberikan dampak pada guru pendidikan agama Islam dalam peningkatan mutu pembelajaran siswa melalui kompetensi IT guru PAI. 
Program atau aktivitas selalu diawali dengan adanya perencanaan yang merupakan salah satu dari fungsi manajemen yang sangat penting. Suatu rencana sangat mempengaruhi sukses dan tidaknya suatu oekerjaan. Oleh karena itu, pekerjaan yang baik adalah yang direncanakan. Dengan demikian dapat diketahui bahwa dalam suatu perencanaan memuat unsur: 1) yang berhubungan dengan masa depan, 2) seperangkat kegiatan, 3) proses yang sistematis, dan hasil serta tujuan tertentu yang hendak dicapai. Perencanaan yang efektif harus melihat fakta, bukan berdasarkan kepada keinginan atau kehendak pribadi. Jadi pembuatan rencana berarti suatu kemampuan menghubungkan pengetahuan atau pengalaman dengan fakta atau keadaan sekarang untuk mencapai tujuan yang akan datang.

Upaya peningkatan pembelajaran siswa melalui kompetensi IT guru PAI, KKG pendidikan agama Islam Kecamatan Ciranjang telah melaksanakan serangkaian kegiatan dengan melakukan berbagai kegiatan yang merupakan bagian dari perencanaan yaitu menyusun instrumen KKG yang terdiri dari pemilihan pengurus KKG maupun menyusun program kegiatan yang berisi jadwal kegiatan, rencana materi yang akan dibahas, merencanakan pembiayaan sampai ke pelaksanaan evaluasi kegiatan. Sedangkan penyusunan program KKG pendidikan agama Islam dilaksanakan oleh pengurus terpilih untuk menyusun rancangan program satu semester di awal semester, dari rencana tersebut kemudian dimatangkan dalam forum KKG PAI secara lengkap. Temuan penelitian menunjukkan bahwa proses penyusunan program KKG PAI dibawah bimbingan pengawas oleh pengurus inti bersama para pemandu untuk menyusun rancangan program satu semester. Program disusun pada awal semester yang materi rancangannya meliputi tanggal, tempat, topik, penyaji, dimana rancangan tersebut kemudian dimatangkan dalam forum KKG.

Upaya mewujudkan tujuan yang hendak dicapai tersebut yakni untuk meningkatkan kompetensi IT guru dalam meningkatkan mutu pembelajaran siswa di KKG PAI Kecamatan Ciranjang. Kelompok kerja guru PAI di Kecamatan Ciranjang telah membentuk serangkaian kegiatan yang diawali dengan pemilihan pengurus kelompok kerja guru beserta seksi atau bidang yang dapat dijadikan sebagai tolak ukur tugas dan tanggung jawab dalam pengimplementasian peran kelompok kerja guru di Kecamatan Ciranjang. Temuan lain menunjukkan bahwa sebelum membentuk program kerja atau program kegiatan kelompok kerja guru PAI di Kecamatan Ciranjang, dibentuk kepengurusan baru. Sementara program KKG PAI diserahkan sepenuhnya pada masingmasing koordinator atau bidang kelompok kerja guru.

Seksi atau bidang dalam kelompok kerja guru di kecamatan Ciranjang ada lima, antara lain sie. Pendidikan dan pelatihan, organisasi dan humas, dakwah dan sosial, kesehatan dan PHBI. Adapun untuk program kerja KKG PAI ini sudah terstruktur sesuai dengan bidang masing-masing. Kepengurusan kelompok kerja guru yang ada di Kecamatan Ciranjang terdiri dari Ketua, Wakil Ketua, Sekretaris, wakil Sekretaris, Bendahara dan Seksi- seksi yang terdiri dari: Sie. Pendidikan dan Pelatihan, Sie. Organisasi dan Humas, Sie. Dakwah dan Sosial, Sie. Kesehatan dan Sie. PHBI (Peringatan Hari Besar Islam).

Berdasarkan uraian tersebut, menunjukkan bahwa program kegiatan KKG PAI Kecamatan Ciranjang yang terbagi dalam masing-masing seksi bertujuan untuk meningkatkan kompetensi guru PAI dan mutu pembelajaran siswa. Kegiatan-kegiatan yang dilaksanakan pada KKG PAI bersifat tentatif dengan bentuk kegiatan yang terdiri atas hal-hal yang terkait dengan peningkatan kompetensi guru PAI dan mutu pembelajaran siswa. Perencanaan program KKG PAI dengan membuat kegiatan dan jika ada hambatan maka anggota KKG memiliki upaya untuk mengatasi hambatan tersebut 
dalam meningkatkan kompetensi IT guru PAI dan mutu pembelajaran siswa secara komprehensif yang disesuaikan dengan kondisi setempat.

\section{b. Pelaksanaan}

KKG PAI SD di Kecamatan Ciranjang Kabupaten Cianjur merupakan wadah atau forum kegiatan profesional semua guru PAI tingkat SD untuk meningkatkan pengetahuan dan kompetensi serta membina hubungan kerja sama secara koordinatif dan fungsional antar sesama guru PAI di Wilayah Kecamatan Ciranjang Kabupaten Cianjur.

KKG PAI SD di Kecamatan Ciranjang Kabupaten Cianjur adalah sebuah organisasi yang di dalamnya memiliki program sebagaimana organisasi yang lain. Adanya program beserta implementasinya menunjukkan bahwa KKG PAI SD di Ciranjang Kabupaten Cianjur merupakan organisasi keprofesian guru PAI SD tingkat kecamatan yang masih aktif dan dapat memberikan dampak pada guru PAI SD dalam peningkatan kompetensi guru. Adapun bentuk program beserta implementasinya akan diuraikan sebagai berikut:

\section{Program KKG PAI SD}

Berdasarkan wawancara dengan ketua KKG, bahwa upaya mewujudkan tujuan yang hendak dicapai dalam meningkatkan kompetensi IT guru, KKG PAI SD Kecamatan Ciranjang telah membentuk serangkaian kegiatan yang diawali dengan pemilihan pengurus KKG beserta seksi atau bidang yang dapat dijadikan tolok ukur tugas dan tanggung jawab dalam mengimplementasikan program KKG.

Lebih lanjut temuan penelitian menunjukkan bahwa program kegiatan KKG memiliki beberapa program yang terbagi dalam lima bidang, antara lain sebagai berikut:

a) Sie Pendidikan dan Pelatihan

Program kegiatan Sie. Pendidikan dan pelatihan memiliki 12 (dua belas) program, yang terdiri dari: (1) penyusunan prota (program tahunan), promes (program semester), dan analisis hari aktif pembelajaran; (2) analisis Kompetensi Inti (KI), Kompetensi Dasar (KD) dan materi PAI di awal tahun ajaran baru; (3) penyusunan silabus, RPP (Rencana Pelaksanaan Pembelajaran) di awal semester secara bersama- sama; (4) tindak lanjut evaluasi dan penilaian dalam proses pembelajaran; (5) pembahasan tentang permasalahan peserta didik, pembahasan tentang pembuatan dan pemanfaatan media yang berkaitan dengan mata pelajaran PAI; (6) penyediaan buku panduan dan pegangan bagi guru PAI SD dalam mata pelajaran PAI; (7) penyediaan buku Lembar Kerja Siswa (LKS), (8) mengirim perwakilan guru PAI SD untuk mengikuti diskusi KKG PAI SD tingkat Kabupaten; (9) Mengirim 5 orang untuk pelatihan Bimtek (Bimbingan dan Teknologi) tingkat provinsi setiap 1 (satu) tahun sekali; (10) mengirim 2 orang untuk pelatihan TIKI (Teknologi Informasi dan Komunikasi Islami) tingkat kabupaten tiap 1 (satu) tahun sekali; (11) mengirim perwakilan guru PAI SD untuk mengikuti pelatihan kurikulum 2013 setiap kali ada pelatihan; (12) mengadakan lomba mata pelajaran dan Seni Islami setiap 1 (satu) tahun sekali.

b) Sie Organisasi dan Humas

Program kegiatan Sie. Organisasi dan Humas memiliki 4 (empat) program, yang terdiri dari: (1) memberikan keterangan baik lesan maupun tertulis kepada atasan dan teman sejawat terkait kegiatan yang akan dilaksanakan; (2) membantu sekretaris dalam penyebaran undangan dan surat-surat penting lain; (3) bertanggung jawab penuh dalam perizinan tempat kegiatan dan lain sebagainya; (4) mengadakan pemilihan kepengurusan (reorganisasi) setiap 3 (tiga) tahun sekali.

c) Sie Dakwah dan Sosial 
Program kegiatan Sie. dakwah dan sosial memiliki 4 (empat) program, yang terdiri dari: (1) mengkoordinasi kegiatan Yasin Fadhilah setiap 1 (satu) bulan sekali (setiap Jum'at); (2) santunan yatim piatu kepada 2 peserta didik dari perwakilan masing-masing sekolah; (3) memberikan $2 \mathrm{Al}$-Qur'an untuk peserta didik yang kurang mampu di masingmasing SD Kecamatan Ciranjang selama masa kepengurusan; (4) mengadakan pesantren kilat di bulan ramadhan bagi peserta didik perwakilan masing-masing SD Kecamatan Ciranjang 2 orang.

\section{d) Sie Kesehatan dan Rohani}

Program kegiatan Sie. Kesehatan dan Rohani memiliki 3 (tiga) program, yang terdiri dari: (1) mengadakan majelis ta'lim setiap 2 (dua) bulan sekali; (2) mengadakan majelis mudzakarah (tanya jawab) dengan mendatangkan narasumber setiap 3 (tiga) bulan sekali; (3) mendatangkan petugas puskesmas untuk memberikan penyuluhan tentang Kesehatan kepada guru PAI untuk disalurkan kepada peserta didiknya di sekolah. e) Sie PHBI (Peringatan Hari Besar Islam)

Program kegiatan Sie. PHBI (Peringatan Hari Besar Islam) memiliki 4 (empat) program, yang terdiri dari: (1) mengadakan pengajian maulid Nabi Muhammad satu tahun sekali; (2) mengadakan pengajian isra'mi'raj satu tahun sekali; (3) mengadakan pengajian nuzulul qur'an satu tahun sekali; (4) mengadakan halal bi halal satu tahun sekali.

Dari uraian tersebut di atas menunjukkan bahwa program kegiatan KKG PAI SD di Kecamatan Ciranjang Kabupaten Cianjur yang terbagi dalam masing-masing seksi (bidang) yang bertujuan untuk meningkatkan kompetensi guru PAI SD yang meliputi: Kompetensi IT, kompetensi sosial, kompetensi kepribadian, dan kompetensi profesional. Untuk melaksanakan hasil perencanaan, maka perlu diadakan tindakan kegiatan. Pengarahan yang dilakukan ketua dalam melaksanakan program yang sudah ada dalam rangka meningkatkan kompetensi IT guru PAI. Pelaksanaan juga melalui berbagai pengarahan dan pemotivasian yang dilakukan oleh ketua pada setiap komponenkomponen KKG PAI Kecamatan Ciranjang untuk melaksanakan kegiatan secara optimal sesuai dengan peran, tugas, dan tanggung jawabnya masing-masing.

Sebagaimana temuan penelitian bahwa pelaksanaan program yang sudah direncanakan dengan memberikan pengarahan dan motivasi kepada pengurus dan anggota sehingga tanggung jawab yang diembannya dalam program kerja dapat dilakukan dengan sebaik-baiknya sesuai tupoksinya. Temuan tersebut diperkuat dengan hasil observasi bahwa pelaksanaan program dalam rangka meningkatkan kompetensi IT guru PAI di KKG PAI Kecamatan Ciranjang telah menjalankan perannya, antara lain:

\section{Peningkatan Efektifitas Pembelajaran}

a) Membahas Pemilihan Metode PAI yang Efektif dan Efesien

Dalam kegiatan ini para guru PAI biasanya mengawali dengan sharing pengalaman mengenai kegiatan belajar-mengajar yang mereka lakukan sehari-hari. kemudian ditemukan metode yang dirasakan kurang efektif dan efisien dalam pembelajaran PAI. Sebagai contoh penggunaan metode ceramah oleh sebagian para guru PAI dirasa kurang menyentuh aspek afektif dan psikomotorik para peserta didik sehingga perlu dikombinasikan dengan metode lain seperti tanya jawab, demonstrasi, atau dengan penggunaan multimedia sebagai pendukung proses pembelajaran. Kegiatan ini akan memberi manfaat kepada guru PAI dalam pelaksanaan pembelajaran di sekolah.

b) Pengembangan Materi PAI 
Hasil wawancara dengan guru-guru PAI yang tergabung dalam KKG Kecamatan Ciranjang Kabupaten Cianjur, materi PAI tingkat SD yang telah direkomendasikan oleh Kementarian Agama dan Kementerian Pendidikan dan Kebudayaan di kurikulum 2013 kurang luas dan mendalam. Sehingga melalui KKG ini para guru PAI bersama-sama membahas tentang pendalaman dan pengembangan materi. Sebelumnya pengurus membagi anggotanya menjadi beberapa kelompok berdasarkan tingkatan kelas, kemudian setiap kelompok tersebut membahas tentang materi dan pengembangannya, akan tetapi masih mengacu pada silabus yang ada, sehingga nantinya tidak akan keluar dari koridor standar kurikulum.

c) Penentuan dan Penetapan Cara-Cara Evaluasi PAI

Evaluasi merupakan cara untuk mengukur hasil belajar peserta didik. Dalam kegiatan KKG PAI ini selain membahas tentang materi dan metode biasanya juga dibahas tentang cara evaluasi, hal ini diawali dengan mengukur sejauh mana efektifitas penggunaan alat penilaian yang digunakan oleh masing-masing guru PAI dalam proses belajar-mengajar di sekolah. Kemudian apabila ada sebagian guru yang merasa kesulitan dalam mengevaluasi hasil belajar peserta didik maka kemudian para guru PAI tersebut memilih cara yang paling tepat untuk mengevaluasi peserta didik dalam pembelajaran PAI.

Adapun peningkatan kompetensi IT guru PAI di KKG PAI Kecamatan Ciranjang Kabupaten Cianjur sebagaimana hasil wawancara dengan ketua KKG bahwa kegiatan yang diselenggarakan oleh KKG dalam upaya peningkatan kompetensi IT guru PAI melalui pelatihan Bimtek (Bimbingan dan Teknologi), pelatihan kurikulum, serta pelatihan Teknologi Informasi dan Komunikasi Islami), studi banding. Hal tersebut terkait dengan KKG PAI SD di Kecamatan Ciranjang Kabupaten Cianjur sebagai organisasi yang selalu berupaya untuk menambah wawasan dan kompetensi anggotanya, yaitu guru PAI terutama dalam penguasaan IT sebagai sarana pembelajaran di sekolah. Dengan demikian maka peningkatan kompetensi IT guru PAI telah terpenuhi melalui program pendidikan dan pelatihan yang ada dalam KKG PAI SD di Kecamatan Ciranjang Kabupaten Cianjur.

\section{c. Evaluasi}

Evaluasi dalam kegiatan proses pelaksanaan KKG mencakup keterlaksanaan kegiatan sesuai dengan yang telah ditetapkan dalam input. Komponen yang akan dipantau dalam kegiatan proses adalah persiapan dan pelaksanaan program kerja yang didukung oleh komponen-komponen input. Evaluasi proses diarahkan pada seberapa jauh program kegiatan KKG dilaksanakan sesuai dengan rencana dan pedoman yang ditetapkan. Berdasarkan hasil penelitian di lapangan bahwa program kegiatan KKG belum semuanya terlaksana hal ini disebabkan karena benturan dengan kegiatan lain. Sehinggga KKG tidak terlaksana, sesuai dengan studi dokumentasi kegiatan KKG yang kami amati bahwa terdapat jadwal kegiatan KKG yang seharusnya berlangsung ternyata tidak berlangsung. Pernyataan tersebut diperkuat oleh hasil wawancara dengan salah satu pengurus KKG bahwa hampir semua program KKG dalam tahun pelajaran ini dapat dilaksanakan sesuai jadwal. Namun demikian, beberapa kegiatan memang mengalami kendala karena berbenturan dengan kegiatan internal sekolah sehingga perlu penyesuaian. Beberapa kegiatan rutin yang belum waktunya tentu belum dilaksanakan.

Kegiatan dalam penyusunan perangkat pembelajaran juga dibahas dalam kegiatan KKG hal ini bertujuan untuk mengatasi kesulitan guru dalam pembuatan perangkat pembelajaran hal ini disadari bahwa belum semua guru menguasai IT sehingga perlu 


\section{Volume 1, Nomor 10, Oktober 2021 p-ISSN 2774-7018; e-ISSN 2774-700X}

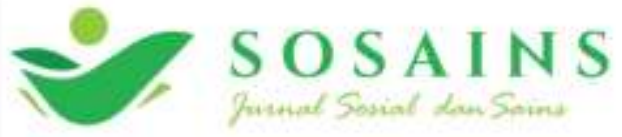

adanya pembahasan mengenai perangkat yang lengkap hal ini disampaikan oleh ketua KKG dalam wawancara dengan peneliti. Bahwa kegiatan penyusunan administrasi pembelajaran merupakan sebuah kebijakan yang disepakati untuk meringankan beban guru dalam membuat administrasi pembelajaran yang sifatnya umum. Memang administrasi pembelajaran merupakan tugas guru secara mandiri, tetapi apakah mungkin semua guru mampu mengerjakan tugas administrasi yang demikian banyak. Maka melalui forum KKG ini para guru diajak secara bersama-sama untuk menyusun perangkat pembelajaran sehingga menghasilkan produk berupa file atau softcopy yang dapat dikembangkan guru secara mandiri di masing-masing sekolah.

Menurut deskripsi di atas dapat peneliti simpulkan bahwa evaluasi program KKG PAI Kecamatan Ciranjang menunjukan proses kegiatan yang berlangsung tidak berjalan sesuai dengan jadwal yang telah ditetapkan hal ini disebabkan karena adanya benturan kegiatan dengan KKG. Adapun evaluasi product adalah evaluasi yang digunakan untuk mengukur keberhasilan pencapaian tujuan. Evaluasi ini merupakan catatan pencapaian hasil dan keputusan-keputusan untuk perbaikan dan aktualisasi. Hasil-hasil yang diperoleh dari kegiatan KKG hendaknya sesuai dengan program kerja yang telah direncanakan meliputi; kebermaknaan pelaksanaan kegiatan dan sejauh mana kegiatan tersebut dapat membantu kesulitan yang dihadapi oleh guru. Terutama dalam penggunaan IT dalam pembelajaran.

Hasil penelitian di lapangan menunjukkan bahwa masih banyak guru PAI di bawah naungan KKG PAI Kecamatan Ciranjang belum mampu menggunakan IT dalam proses pembelajaran. Padahal KKG PAI Kecamatan Ciranjang sudah berupaya untuk mengadakan bimbingan dan pelatihan dalam meningkatkan kompetensi IT guru PAI dengan harapan mampu mengaplikasikannya dalam proses pembelajaran di sekolah masing-masing. Dari paparan di atas dapat disimpulkan bahwa pelaksanaan pelatihan dalam upaya meningkatkan kompetensi IT guru PAI di KKG Kecamatan Ciranjang belum maksimal terutama dalam pengembangan kemampuan IT guru PAI di KKG PAI Kecamatan Ciranjang.

\section{d. Faktor Pendukung dan Penghambat}

\section{1) Pendukung}

Keberhasilan dalam pengembangan keprofesian guru dan peningkatan kompetensi guru khususnya kompetensi IT melalui pelaksanaan program KKG PAI SD di Kecamatan Ciranjang Kabupaten Cianjur sangat ditentukan oleh sikap positif para guru PAI SD serta dukungan dari birokrasi dan masyarakat terhadap setiap program yang telah disusun. Adanya dukungan para guru, birokrasi, dan masyarakat terhadap pelaksaaan kegiatan KKG PAI SD di Kecamatan Ciranjang Kabupaten Cianjur didasarkan pada integritas peneliti dari pernyataan rumusan temuan peneliti sebagai berikut: 1) telah disadari bahwa profesionalisme guru dalam peningkatan kompetensi guru mempunyai pengaruh yang sangat besar terhadap mutu pendidikan, 2) telah disadari bahwa kegiatan KKG PAI SD sangat membantu dalam rangka peningkatan kompetensi guru, terutama dalam bidang kompetensi IT, 3) program yang disusun berdasarkan pada materi pembelajaran guru PAI SD di sekolah masing-masing perlu mendapatkan perhatian dan pembahasan.

Apabila melihat uraian di atas, maka beberapa faktor pendukung pelaksanaan program KKG PAI SD dalam peningkatan kompetensi IT guru PAI di Kecamatan Ciranjang Kabupaten Cianjur antara lain adalah: (a) faktor pendidikan, (b) faktor usia, (c) faktor motivasi. Faktor pendidikan menjadi faktor pendukung, karena dari semua guru PAI SD yang berjumlah 48 (empat puluh delapan) di Kecamatan Ciranjang Kabupaten Cianjur memiliki kualifikasi akademik dalam bidang Pendidikan Agama Islam (PAI), dan telah menempuh Pendidikan minimal D-II, S-1 dan ada pula yang S-2. Begitu pula 
dengan faktor usia dan motivasi menjadi faktor pendukung sebab kondisi usia para guru PAI SD yang bermacam-macam menjadikan semangat dan motivasi guru PAI SD yang tinggi untuk meningkatkan wawasan, pengetahuan dan keterampilan di bidangnya. Semisal guru PAI SD yang tergolong masih muda, terampil dan cakap dapat membantu para guru PAI SD yang senior.

\section{2) Penghambat}

Adapun faktor penghambat pelaksanaan program KKG PAI SD Kecamatan Ciranjang Kabupaten Cianjur dalam peningkatan kompetensi IT guru, antara lain: (a) faktor sarana dan prasarana, (b) faktor dana, (c) faktor penguasaan IT yang belum maksimal dan merata. Minimnya sarana dan prasarana yang dimiliki oleh KKG PAI SD di Kecamatan Ciranjang Kabupaten Cianjur menjadi salah satu faktor penghambat dalam pelaksanaan peningkatan kompetensi IT. Belum tersedianya komputer/ laptop serta LCD dan proyektor milik KKG PAI SD di Kecamatan Ciranjang Kabupaten Cianjur sehingga menghambat dalam hal teknologi dan keadministrasian yang masih seringkali menumpang pada lembaga sekolah tertentu atau individu tertentu, tidak adanya fasilititas seperti modem yang dapat digunakan ketika ada tugas dinas secara online (sebagai contoh) dirasa menghambat dalam hal sarana dan prasarana KKG PAI SD di Kecamatan Ciranjang Kabupaten Cianjur.

Faktor selanjutnya yang menghambat adalah pada permasalahan dana. semisal ketika ada lomba Mata Pelajaran dan Seni Islami yang membutuhkan banyak dana, padahal dana yang ada dalam KKG PAI SD masih minim dan terbatas. Sebab, lomba tersebut merupakan salah satu program KKG PAI SD di Kecamatan Ciranjang Kabupaten Cianjur yang berkenaan dengan kompetensi IT. Sebagaimana wawancara dengan sie pendidikan dan pelatihan bahwa salah satu yang menghambat pelaksanaan KKG PAI SD dalam meningktakan kompetensi IT guru PAI adalah pembiayaan atau dana setiap kali akan ada kegiatan. Meskipun memang ada iuran rutin di antara guru PAI KKG, namun terkadang masih kurang .

Selanjutnya, faktor lain yang penghambat pelaksanaan KKG PAI SD dalam peningkatan kompetensi IT di Kecamatan Ciranjang Kabupaten Cianjur adalah banyaknya guru senior yang belum cukup menguasai IT dan gadget. Sebagaimana hasil wawancara dengan ketua KKG bahwa kurangnya teman-teman guru PAI SD dalam menguasai IT dapat menghambat tugas- tugas yang harus segera diselesaikan dan ditindaklanjuti, terutama banyak sekali yang berhubungan dengan sie. Pendidikan dan pelatihan ketika penyusunan silabus dan RPP, analisis SK, KD dan Indikator.

Dengan begitu, tidak sedikit pula guru-guru PAI muda yang harus mengajari guru PAI senior dalam penggunaan laptop/notebook/gadget. Karena dalam penyusunan silabus, RPP, prota, maupun promes, guru PAI dituntut untuk terampil dalam penggunaan IT (Informasi dan Teknologi). Sehingga guru PAI harus meningkatkan kualitas dirinya dalam penggunaan IT yang menjadi tuntutan di abad ke-21 ini. Bahkan sekarang KKG PAI SD di Kecamatan Ciranjang Kabupaten Cianjur minimal harus memiliki handphone android untuk lebih mudah berkomunikasi melalui aplikasi whatsapp.

Berbagai uraian di atas dapat disimpulkan bahwa pelaksanaan program KKG PAI SD adalah sebagai wadah atau forum dalam peningkatan kompetensi IT guru di Kecamatan Ciranjang Kabupaten Cianjur. Dalam pelaksanaan tersebut, maka tak dapat lepas adanya faktor pendukung dan penghambat yang ada di dalamnya sebagaimana yang telah diuraikan di atas. Dengan adanya factor penghambat dalam peningkatan kompetensi 
IT tersebut, maka dapat menjadi pijakan dalam perbaikan-perbaikan yang harus dilakukan oleh semua pihak baik Dinas, UPT Pendidikan Kecamatan, pengurus KKG, dan seluruh anggota KKG PAI SD di Kecamatan Ciranjang Kabupaten Cianjur agar dapat tercipta peningkatan mutu pendidikan khususnya dalam proses pembelajaran di kelas yang berkaitan antara pendidik dan peserta didik.

\section{Manajemen Pelatihan Guru PAI dalam Meningkatkan Kompetensi IT Untuk Mewujudkan Mutu Pembelajaran Siswa di KKG PAI Kecamatan Takokak}

a. Perencanaan

Perencanaan adalah langkah pertama dalam proses manajemen. Perencanaan yang baik akan memiliki implikasi yang baik pula pada langkah selanjutnya dalam pelaksanaan kegiatan. Karena dalam pelaksanaan terdapat landasan berpijak dan koridor-koridor pelaksanaan kegiatan. Dalam teori manajemen perencanaan atau planning menempati posisi penting dalam sebuah penetapan program kerja. Perencanaan sama halnya melakukan pemetaan awal terhadap sebuah persoalan yang harus dipecahkan. Perencanaan tersebut meliputi penetapan tujuan, penetapan waktu pelaksanaan, penetapan tempat pelaksanaan, peserta, penetapan nara sumber dan pembiayaan.

\section{1) Penetapan Tujuan}

Tujuan pelatihan yang dilakukan oleh KKG PAI SD Kecamatan Takokak dibuat secara sederhana. Tujuan tersebut tidak pernah dituliskan dalam sebuah 'kertas blue print, namun hanya tertuang dari jadwal-jadwal kegiatan tersebut. Hal ini sebagaimana banyak diungkapkan oleh pengurus KKG PAI. Secara lebih rinci sebagaimana hasil wawancara dengan ketua KKG,

Peneliti melihat tujuan pelaksanaan pelatihan lebih diarahkan pada:

a) Peningkatan profesionalisme guru PAI untuk melaksanakan kegiatan belajar mengajar di kelas masing-masing.

b) Menyetarakan kemampuan dan kemahiran guru PAI dalam melaksanakan kegiatan belajar mengajar sehingga dapat menunjang usaha peningkatan dan pemerataan pendidikan.

c) Mempersiapkan guru peserta KKG PAI dalam memahami, mengkaji, dan melaksanakan kurikulum terbaru.

d) Mempersiapkan peserta KKG PAI untuk dapat menentukan metode, materi, dan evaluasi yang tepat.

e) Mendiskusikan bersama dan mengkonsultasikannya dengan para ahli yang kebetulan diundang dalam KKG.

f) Memberikan informasi terbaru dari berbagai pihak, baik dari pemateri atau bahkan antar peserta KKG itu sendiri.

Tujuan ini merupakan tujuan yang realistis, terukur dan spesifik bagi guru-guru PAI SD Kecamatan Takokak. Tujuan tersebut realistis karena telah disusun berdasarkan konsep profesionalisme yang harus dimiliki guru. Sebagaimana hasil wawancara dengan salah satu pengurus KKG PAI Kecamatan Takokak bahwa ciri-ciri guru profesional adalah guru yang memiliki komitmen pada siswa dan proses belajar, menguasai secara mendalam bahan atau mata pelajaran, bertanggung jawab dalam proses pembelajaran. Selain itu guru professional juga memiliki karakter berfikir sistematis tentang apa yang dilakukannya dengan belajar dari pengalamannya.

\section{2) Penetapan Waktu Pelaksanaan}


Penetapan waktu pelaksanaan KKG PAI SD Kecamatan Takokak biasanya disesuaikan dengan jadwal kegaitan rutin KKG. Namun jadwal tersebut juga bersifat fleksibel, artinya akan ditinjau ulang menjelang waktu pelaksanaan. Apakah memungkinkan dilaksanakan pada jadwal yang telah ditetapkan, apakah pemateri memiliki waktu sesuai jadwal yang ditetapkan, dan apakah tidak ada kendala yang lain.

\section{3) Penetapan Tempat Pelaksanaan}

Tempat pelaksanaan KKG PAI SD Kecamatan Takokak dilaksanakan secara fleksibel, artinya tempat pelaksanaan tidak bersifat permanen pada suatu tempat. Hal ini disebabkan oleh tidak adanya tempat pertemuan khusus yang menjadi base camp atau sekretariat bersama. Hal ini berbeda dengan KKG yang telah memiliki sekretariat bersama untuk melakukan kegiatan dan pengolahan administrasi organisasi. Kondisi ini juga nantinya berimbas pada persoalan lain, seperti kendala-kendala yang banyak dihadapi pengurus dan anggota KKG PAI SD Kecamatan Takokak.

Dengan demikian tempat pelaksanaan KKG PAI SD Kecamatan Takokak akan sangat tergantung oleh kesiapan peserta KKG untuk memberikan kesempatan tempat di sekolah masing-masing peserta. Tempat pelaksanaan menjadi sangat fleksibel tergantung pengurus atau peserta mana yang bersedia menyiapkan tempat pelaksanaan.

\section{4) Peserta Pelatihan}

Peserta pelatihan merupakan peserta KKG SD PAI Kecamatan Takokak. Peserta ini bersifat tetap kecuali ada penambahan baru. Peserta KKG PAI SD Kecamatan Takokak sendiri berjumlah 33 Guru. Namun setiap pelaksanaan kegiatan tidak semua guru bisa datang, jumlah yang bisa menghadiri kegiatan KKG berkisar antara 95 persen dari jumlah peserta. Namun secara keseluruhan peserta KKG PAI SD Kecamatan Takokak boleh dibilang aktif.

\section{5) Penetapan Pemateri}

Pemateri ditepatkan berdasarkan beberapa pertimbangan. Pertama, pemateri dipilih karena kompetensinya untuk menyampaikan materi yang diinginkan oleh peserta KKG PAI SD Kecamatan Takokak sesuai dengan kesepakatan yang telah disusun sejak awal. Kedua, pemateri dipilih karena memiliki akses informasi terkait dengan kebijakankebijakan pendidikan, khususnya PAI dan secara regional adalah kebikakan pendidikan . Ketiga, kedekatan emosi dengan peserta KKG PAI SD Kecamatan Takokak. Kepengurusan KKG PAI SD Kecamatan Takokak biasanya mengundang pemateripemateri yang telah mereka kenal dan mudah untuk menghubunginya.

\section{6) Pembiayaan Pelaksanaan Pelatihan}

Pembiayaan pelaksanaan pelatihan ditanggung oleh KKG PAI SD Kecamatan Takokak secara organisatoris. Pembiayaan tersebut berasal dari dana yang diperoleh dari Dinas Pendidikan Kabupaten. Pembiayaan biasanya bersifat umum, karena semua pembiayaan dalam KKG PAI sama, dalam arti pengeluaran baik untuk keperluan konsumsi, alat tulis, penggandaan materi, pesangon untuk pemateri hingga peserta dari waktu ke waktu sama. Hanya saja dana yang tersedia dari Dinas Pendidikan sangat terbatas tidak jarang peserta KKG harus mengeluarkan biaya sendiri untuk melangsungkan kegiatan. Iuran anggota yang bersifat tentatif menjadi pilihan untuk membiayai kegiatan KKG tersebut. 


\section{Kesimpulan}

Pelaksanaan program-program KKG PAI SD Kecamatan Ciranjang dan Takokak Kabupaten Cianjur yang meliputi tempat kegiatan yang belum memadai, sarana dan prasarana yang perlu dilengkapi, kedisiplinan yang belum maksimal, serta faktor dana yang tidak memadai. Namun demikian, keadaan ini tidak mengurangi kreativitas dan semangat untuk merancang serta melaksanakan kegiatan dan tugas dengan baik demi mewujudkan kualitas pendidik agama yang profesional dan berkualitas di masa datang.

\section{Bibliografi.}

Afifuddin, Muchammad. (2017). Pengembangan Media Pembelajaran PAI Berbasis ICT. TARBAWI, 6(2), 141-156.

Anggreni, Ni Made. (2016). Konstruksi Budaya Mutu Relevansinya Dengan Manajemen Mutu Guru Dalam Pembelajaran Pendidikan Agama Hindu. Jurnal Penjaminan Mutu, 2(2), 84-92.

Asilestari, Putri. (2016). Retracted: Komputer Interaktif sebagai Media Pengajaran Bahasa Inggris pada Anak Usia Dini. Jurnal Obsesi: Jurnal Pendidikan Anak Usia Dini, 2(1), 55-62.

Batubara, Hamdan Husein. (2015). Pengembangan media pembelajaran interaktif pada materi operasi bilangan bulat. Muallimuna: Jurnal Madrasah Ibtidaiyah, 1(1), 1-12.

Mulyasa, Endang. (2013). Uji kompetensi dan penilaian kinerja guru. Bandung: PT Remaja Rosdakarya.

Mulyawan, Budi. (2013). Pengaruh pengalaman dalam pelatihan terhadap peningkatan kompetensi profesional guru. Media Komunikasi FPIPS, 11(1).

Niarsa, Aditiya. (2013). Studi Kompetensi Guru Dalam Memanfaatkan Media Pembelajaran Berbasis Teknologi Informasi Dan Komunikasi (TIK) DI SD Negeri 01 Ledok Kecamatan Sambong Kabupaten Blora. Semarang: Universitas Negeri Semarang.

Nugroho, Iwan, Pramukanto, Fiqih Hari, Negara, Purnawan D., Purnomowati, Wiwin, \& Wulandari, Wahju. (2016). Promoting the rural development through the ecotourism activities in Indonesia. American Journal of Tourism Management, 5(1), 9-18.

Rivalina, Rahmi. (2015). Kompetensi Teknologi Informasi dan komunikasi guru dalam peningkatan kualitas pembelajaran. Jurnal Teknodik, 165-176.

Rohmad, Abdul. (2014). Hubungan Antaraefikasi Diri Dengan Kinerja Pada Guruyang Mengajar Di Jurusan Akuntansi Pada Smk Negeri Se-Kota Jakarta Timur. Jakarta: Universitas Negeri Jakarta.

Sauri, H. Sofyan. (2019). Pengertian Nilai. Bandung: Diakses Melalui file. upi. edu, Pada.

Sauri, Sofyan. (2017). Nilai Kearifan Pesantren. Bandung: Edited by Mohamad Zaka AlFarisi. Bandung: Rizqi Press.

Sulfemi, Wahyu Bagja. (2019). Kemampuan pedagogik guru.

Uno, Hamzah B., \& Lamatenggo, Nina. (2016). Tugas Guru dalam Pembelajaran. Jakarta: Bumi Aksara.

Utomo, Anang Budi. (2016). Pengembangan Model Manajemen Pelatihan Pembelajaran Chemo-Entrepreneurship (CEP) Terintegrasi Soft Skill Bagi Guru Kimia SMA di Kota Semarang. Semarang: Uniersitas Negeri Semarang. 


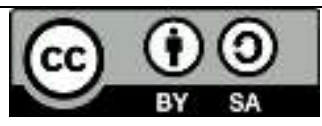

This work is licensed under a Creative Commons Attribution-ShareAlike 4.0 International License. 